\title{
PTK7 wt Allele
}

National Cancer Institute

\section{Source}

National Cancer Institute. PTK7 wt Allele. NCI Thesaurus. Code C52375.

Human PTK7 wild-type allele is located within 6p21.1-p12.2 and is approximately $85 \mathrm{~kb}$ in length. This allele, which encodes tyrosine-protein kinase-like 7 protein, plays a role in tyrosine kinase signal transduction and may be involved in cellular adhesion. 